\title{
Research on Coordination Development Paths for Technology Capacity and Technology Management Capacity
}

\author{
Yan-Li XU, Ya-Xin WANG \\ School of Business \\ Lingnan Normal University \\ Zhanjiang, Guangdong, P. R. China, 524048 \\ xuyanli_2010@126.com
}

\author{
Jin-Hui TANG \\ School of Economics \& Management \\ Guangdong University of Petrochemical Technology \\ Maoming, Guangdong, P. R. China, 525000
}

\begin{abstract}
This paper aims at finding an implementation path to promote the coordinated development of technology capability and technology management ability. This paper analyzes the technical ability and management ability, and their relationship in the equipment manufacturing industry briefly. Through deductive induction and comparative analysis, it has been studied that the relationship between them and their respective characteristics. Finally the path model of the collaborative development of technical ability and technology management capability is constructed.
\end{abstract}

Keywords-technical ability; technical management ability; coordinated development; realized path

\section{OVERVIEW}

With the development of The Times, we gradually take step into the era of knowledge economy and big data, technology plays an important role in the development of an enterprise and country, more and more countries and enterprises pay attention to the study of technology in this field. On the one hand technical ability is important, on the other hand we cannot ignore that how to make the technical ability to play a real role. To realize this we need to solve the problem how to manage the technology, in the other word the technology management ability. Here, having technical ability is the premise condition, technology management ability is a promotion of technology method, no technical skills, no management ability of the technology; No technical management ability as a solid backing, technical ability can't really play its role. Especially in the equipment manufacturing industry, in the past, many companies are often more to pursue the development of technical ability, and ignore the role of technical management in enterprise production and the interaction mechanism between the technical ability. Technical ability, on the other hand, the development of the prior to the development of the technology management ability, on the one hand, it creates an uncoordinated development between is not synchronized, the truth is that only the formation of the coordinated development of both steps to make an enterprise or a industry development.
Industry competitiveness of the United States was once a recession, although the reason for America's industry technology development is not poor, but you can't make rapid response to market conditions and opportunities in time, it is not they are unable to develop new technologies, but can be used in the management of technical blunder ${ }^{[1]}$. So technology ability and the ability to manage both the coordinated development of work in the development of equipment manufacturing industry is the same, only the truly achieve coordination, or balance, industry to proceed steadily. If technical ability is strengthened and the ability to manage is to keep up with, also can only say that there is no direction forward, unable to truly make the industry forward. An industry to develop, in addition to the development of technical ability development, should not be forgotten more importance on the ability of the management and timely and appropriate update, so as to make the technical ability in the right position, play a role in a right way, promoting industrial development and competitiveness for the enterprise to add new power.

\section{The Relationship BETWEEN TECHNOLOGY CAPACITY AND TECHNOLOGY MANAGEMENT CAPACITY}

In the equipment manufacturing industry, the development, technical ability and management ability to coordinate, and both wants to coordinate, should be to increase development together, so as to promote the development of the industry, the development of relations as shown in figure 1 .

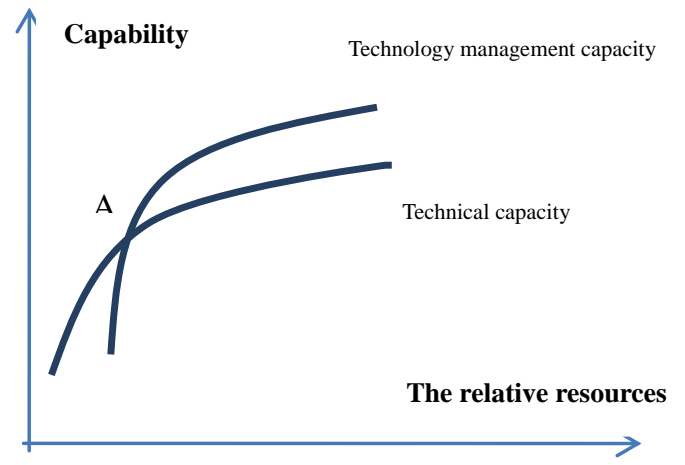

Fig. 1. Relationship diagram of technology capacity and technology management capacity 
From figure 1 shows the relationship between technology capacity and technology management capability and enterprise resources in various aspects are concerned, if the resources use undeserved, may cause the enterprise internal appeared two kinds of results:

(1) Excessive resources for technology development, technology management capacity to keep up with the pace, so as to make the decision;

(2) The resources used in the technology development, technology development too slow, ability is low, cause though technology management capability and technical ability can't keep up.

For the utilization of resources and to technical management ability, embodies the importance of it, on the other hand, requires the ability to obtain information of the ability to work to gain insight into companies and the external environment. Assumptions at point $\mathrm{A}$, to balance, then the enterprises in the technology management capability and technical ability of resource input, namely the coordinated development, through technical management ability to get resources from external provide basis and reference for the development of technological capability, technology capability by updating and development provide the conditions for the enterprise and management. But in reality, not as a model of equilibrium at point $\mathrm{A}$, but around point $\mathrm{A}$ small scale fluctuation can seem both of coordination.

\section{RESULTS AND DISCUSSION}

\section{A. The Brief of Development of Technical Competence}

Technology refers to the sum of biochemical knowledge stock in enterprise as to support technology innovation reality, attaching the internal personnel, equipment, information and organization. Its essence is the knowledge owned by the enterprise. By definition, technical ability belongs to the enterprise internal knowledge, first is personnel, second is equipment, third is information, and fourth is the stock of knowledge. The author believes that the equipment manufacturing industry technical ability belongs to the interior of the enterprise system, its composition as shown in TABLE I.

TABLE I. INTERNAL RELATIONS WITH TECHNICAL ABILITY

\begin{tabular}{|c|c|}
\hline $\begin{array}{l}\text { Elements of } \\
\text { constitution }\end{array}$ & Requirements and significance to the enterprises \\
\hline Personnel scale & $\begin{array}{l}\text { shows the human resources that can be callable in the } \\
\text { internal of enterprise (including intelligence and } \\
\text { knowledge) }\end{array}$ \\
\hline product brand & $\begin{array}{l}\text { decides the enterprise market as well as the influence } \\
\text { and feasible }\end{array}$ \\
\hline $\begin{array}{l}\text { The quality of } \\
\text { equipment }\end{array}$ & $\begin{array}{l}\text { it is related to the capability of development and } \\
\text { productivity }\end{array}$ \\
\hline $\begin{array}{l}\text { The quality of } \\
\text { product }\end{array}$ & it relates to enterprise market volume and feasible way \\
\hline
\end{tabular}

Know from table 1, to improve the technical ability of the equipment manufacturing industry, we should start from the personnel, the brand of product, the quality of equipment and product these several major aspects. The author believes that on the way to improve technical ability in the equipment manufacturing industry field, we should tackle them from the product brand firstly, and then to mobilize available resources within the enterprise- the personnel, thus a breakthrough in terms of quality of equipment and products, to promote the long-term development of enterprise industry and progress.

Experience in the development of technological capability studies, mainly experienced three stages: origin, preliminary formation stage, development stage theory ${ }^{[2]}$.The main course such as TABLE II.

TABLE II. THE DEVELOPMENT OF TECHNICAL ABILITY

\begin{tabular}{|l|l|}
\hline $\begin{array}{c}\text { technical ability } \\
\text { development stage }\end{array}$ & \multicolumn{1}{c|}{$\begin{array}{c}\text { Time and sign of technical ability development } \\
\text { stage of development }\end{array}$} \\
\hline Origin phase & $\begin{array}{l}\text { began in the } 60 \text { s, representative views have arrow } \\
\text { "study form doing" and "study in using" rosenberg }\end{array}$ \\
\hline $\begin{array}{l}\text { Theory of preliminary } \\
\text { formation stage }\end{array}$ & $\begin{array}{l}\text { Martin lassman and g nice hosted by Ken subject as } \\
\text { well as in the } 80 \text { s "third world 'technological } \\
\text { capabilities", "based on the development of the } \\
\text { technology" project completed }\end{array}$ \\
\hline Stage of development & $\begin{array}{l}\text { in the late } 80 \text { s, which is divided into macro and } \\
\text { micro two parts }\end{array}$ \\
\hline
\end{tabular}

From table 2, study on technology of today has entered the stage of development, and in this phase is divided into the study of macro and micro. Obviously, for only a or single equipment manufacturing enterprise refers to the equipment manufacturing industry, more research should be devoted to the micro part and in order to improve its internal technical ability, and macro aspects should with technical management ability as a backing for technical ability to promote and drive.

\section{B. Technology Management Capacity Development Briefly}

Technical management skills include the cultivation of the ability to new technology, development, and then to use new technology for production and technology and technology and used with joint and analysis of application effect between and use management.

Is mentioned above, the technical ability for the enterprise internal, so technical management ability is the enterprise and the external environment of mediation, it should be based on the research of the enterprise external environment analysis, and then applies useful information within the enterprise technical ability, it is the external environment of the market information used to transmit information plus the effective use of internal resources, the effective utilization of human resources and equipment resources, combine internal and external, carries on the analysis and evaluation, finally the technical ability of the enterprise or industry, reasonable use, make full use of temperate, planned and purposeful use of 
appropriate management, so as to make the enterprise management benefit maximization and the technical ability of application of utility maximization, thus promote the progress of the enterprise.

\section{THE TECHNOLOGY AND THEIR MANAGEMENT SKILLS AND SECHNICAL ABILITY COORDINATED DEVELOPMENT PATH}

For technical management ability of ascension path, this paper argues that can consider from the following three aspects:

(1) Establish a perfect management system, perfect the system of the enterprise management theory and outline, and develop enterprise personnel technical management quality;

(2) analyze the market demand, independent innovation, with independent product brand market;

(3) To establish evaluation system of information analysis and application and multi-angle cooperation ability development and innovation of technology.

For the development of technical ability, at different stages in different countries have different performance: in developed countries, the development of the technical ability have transition from basic industry to the technological ability of high and new technology industry development stage. While in developing countries, from the beginning of the generic technical ability to imitate and stepped into the stage of technical independent innovation ability of development. The development of both paths as shown in figure 2 and figure 3, respectively

Technology capacity level

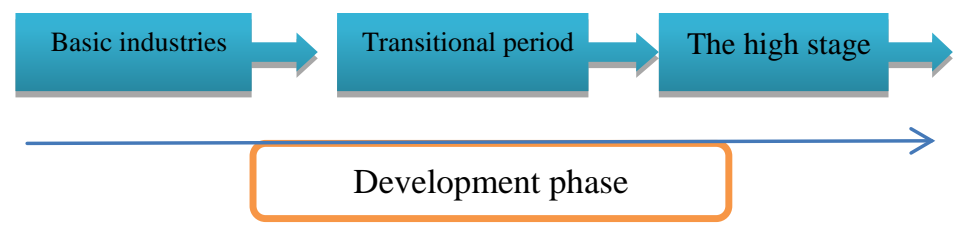

Fig. 2. Technical ability in the developed countries

Technology capacity level

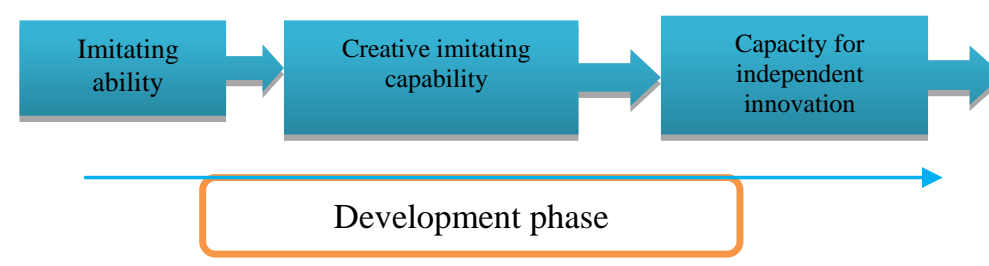

Fig. 3. Technical performance in developing countries
By figure 2 and figure 3 shows that the current no matter from the point of developed countries and developing countries, a company or industry to get better and more longterm development, must keep pace with times, that is, from macroscopic world understanding microscopic industrial environment of enterprise, must focus on developing new independent innovation products, for the equipment manufacturing industry is also so, should focus on the enterprise independent innovation ability, and the ability to relate to use in high and new product development. On the basis of improve the technical ability of enterprise.

And on the other hand, although the technology management capability and technical ability are improved, but only by the progress of management or technical skills blindly does not pull the industry development, should their technical management skills and technical capabilities enhance mutual promotion, management ability for the technical ability to back it up with technology, with the technical ability for the technical management capabilities to provide the necessary power and related equipment, and, in turn, use of technology management capability to manage technical ability, both should be driven relationship between each other, can't just unilaterally advance and development of such a unilateral development is unable to make the enterprise get promoted. So the coordinated development between Technology management capacity and Technical capacity can be expressed in the following model that shown in figure 4.

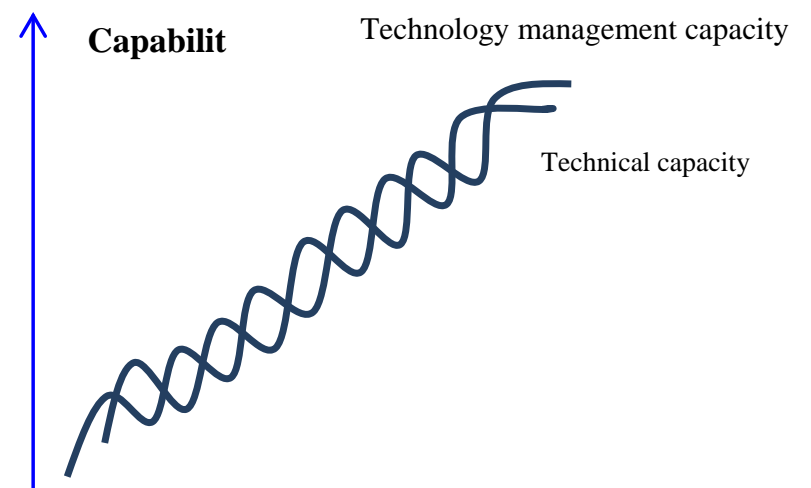

The relative importance

Fig. 4. The coordinated development of technology capacity and technology management capacity

From figure 4 analysis technology capacity and technology management capacity between the coordinated development path, as you can see, technology capacity and technology management capacity in the reality cannot achieve full synchronization, but increases the ascension into a double spiral curve, the intersection point in the graph is to realize the coordinated development of both, when after the intersection point will appear or technical ability development degree is higher than the technical management ability development degree or technical ability development degree is lower than the technical management ability of uncoordinated condition, 
at this point, according to the figure 4, enterprises should timely adjust the importance between the (development), until further coordination, both between is rising because of the synergy of internal and external development promotes the common form.

Thus, though progress has a great influence for enterprise technical ability, but can clearly see the importance of technical management ability in the enterprise development. Technology capacity and technology management ability is the unity of a pair of complementary to each other, today's equipment manufacturing industry enterprise as a member of the knowledge era, the renewal speed of progress is bound to keep up with The Times, constantly upgrade themselves, and this will have to rely on technology ability and the ability to manage both work together.

Although get good economic development of China in recent years, but the level of enterprise technology in China fully development, especially in today's China's industrial development has entered the stage of independent innovation, as a production base of equipment manufacturing industry should be more aware of this, should be in the history of the United States at that time, the loss of competitiveness is a guide. The more at this stage, as a link to the internal and external environment of the intermediate links, technical management ability is particularly important, in this stage, only give full play to the role of, can make a correct analysis, this stage of the technical ability, though important, seemingly industry competitiveness is focused on technical ability, but it is in terms of technical management ability, technical ability is a reflection of competitiveness, only update technical management ability to keep up with The Times environment, enterprises can truly make right judgment of the market and industry change to make the development of the technical ability training and updated to meet the needs of market and enterprise development.

\section{ACKNOWLEDGMENT}

It is a pleasure to acknowledge the support of the project from XU Yan-li being selected in the introduction of shortage top talent of "Sailing up (Yangfan) project" in Guangdong Province in 2014. The project is Leading Industry Development Strategy Research in Emerging Areas in Western Guangdong for Accelerating the Economic Development of Western Guangdong.

It is a pleasure to acknowledge the support from the talents introduction project of universities in Guangdong Province. The project is the Coordinating Development Model Construction and the Path Research of Technical Capability and Technology Management Capability in Equipment Manufacturing Industry.

It is also a pleasure to acknowledge the support from Research Base of Practicing the Scientific Development Outlook of Guangdong Province (2014JD08, 2014JD09), Research Base for the Coordinated Development of Urban and Rural Areas, Outstanding New Majors Project (11428), Collaborative Innovation Center for Silk Road in Southern China Sea, Regional Development Research Institute in Western Guangdong, etc, in Lingnan Normal University.

\section{REFERENCES}

[1] Da-peng Liang; Wei-wei Wu; zhigangwang. Industrial technology capacity and technology management capacity of synergy range and measure model. Scientific decision [J]. 2009, 11

[2] Wei jiang. Enterprise technical ability research and reviewed. The development of scientific management study [J]. 2000 (10), 18-25.

[3] Xiao-qing Zhao, qing-rui Xu. Enterprise technical ability evolution path. Scientific research management [J]. 2002 (01), 1-23.

[4] Chun-hui Tang; yaojia Tang. Enterprise technical ability and the technological innovation pattern analysis. Journal of liaoning university (philosophy and social sciences edition) [J]. 2006 (01), 1-34 